\title{
The radiosensitization effects of Endostar on human lung squamous cancer cells $\mathrm{H}-520$
}

\author{
Zhen Y You', Yong Zhao'2, Feng Liu', Ying D Zhang'1 and Jun J Wang*
}

\begin{abstract}
Background: The present study mainly aimed to investigate the direct effects of Endostar (ES) on the proliferation and radiosensitivity of human lung squamous cancer cell line $\mathrm{H}-520$.

Results: ES significantly inhibited $\mathrm{H}-520$ cell proliferation in a time- and dose-dependent manner. According to the colony-forming assays, ES could increase the $\mathrm{H}-520$ cell radiosensitivity. ES induced cell apoptosis, the apoptosis rate increased with the raise of ES concentration. Irradiation induced significantly higher apoptosis rate in ES-treated H-520 cells than non-treated $\mathrm{H}-520$ cells. ES induced cell cycle distribution and $\mathrm{G}_{0} / \mathrm{G}_{1}$ arrest in $\mathrm{H}-520$ cells, whereas irradiation induced $\mathrm{G}_{2} / \mathrm{M}$ arrest. The phospho-p38-MAPK and p-Akt protein levels were decreased in $\mathrm{H}-520$ cells after ES treatment. Furthermore, activated caspase protein level increased and $\mathrm{Bcl}-2$ protein levels decreased after treatment with ES and irradiation.

Conclusion: $\mathrm{ES}$ significantly enhanced the sensitivity of $\mathrm{H}-520$ cells to irradiation by inhibition of cellular proliferation, promotion of cell apoptosis and redistribution of cell cycle, possibly via deactivation of Akt pathway. The present study supports the possibility to use the combination of ES and ionizing irradiation to treat patients with lung squamous cell cancer in clinics.
\end{abstract}

\section{Background}

About $40 \%$ of patients with stage III or IV non-small cell lung carcinoma (NSCLC) cannot be resected at present [1]. Radiotherapy and chemotherapy are still the major treatment in such patients and significantly improves the survival of unresectable patients [1-3]. Nevertheless, long-term survival remains poor and mortality is high. Anti- angiogenesis therapy that interfered with cancer angiogenesis may improve lung cancer patient survival by enhancing radiation and chemotherapy efficiency without increasing treatment-related adverse effects [4-7].

Endostatin (ED) is a $22 \mathrm{kDa}$ polypeptide derived from the C-terminal fragment of type XVIII collogen. Both recombinant human and murine ED have been reported to inhibit endothelial cell proliferation but not smooth muscle cells or fibroblast proliferation in vitro, which suggested that the anti-proliferation effect was endothe-

* Correspondence: doctorwangjunjie@yahoo.com.cn

1 Cancer Center, Department of Radiation Oncology, Peking University Third

Hospital, Beijing 100191, China

Full list of author information is available at the end of the article lial-specific $[8,9]$. The anti-angiogenic activity of ED was a complicated process resulting in the inhibition of endothelial cell adhesion, migration and proliferation as well as the induction of apoptosis [10,11]. It has been shown that ED bind specifically to the cell surface receptor on the endothelial cells and the complex of ligandreceptor was internalized into the cells [12-14]. The integrin $\alpha_{v}, \alpha_{5}, \beta_{1}$ and cell surface glypicans and nucleolin have been identified as receptors interact with ED [1416]. Recently, the anti-tumor effects of ED have been reported. Wilson et al reported that ED inhibited migration and invasion of head and neck squamous cell carcinoma cells [17]. Cui et al reported that ED directly modulated lung cancer cell function in vitro [18]. Dkhissi et al demonstrated that ED exhibited a direct anti-tumor effect in addition to its anti-angiogenic activity in colon cancer cells [11]. All these results suggested that ED could interact with not only endothelial cells but also cancer cells. However, it was not reported whether ED directly modulates NSCLC cell function such as proliferation, apoptosis and cell cycle distribution or whether it 
has the ability to enhance radiosensitization activity in NSCLC cells.

Endostar (ES) is a novel recombinant human ED which expressed and purified in E. coli, and was approved by the State Food and Drug Administration (SFDA) for the treatment of NSCLC in 2005 [19]. ES is traditional ED with an additional nine-amino acid sequence at the Nterminal of the protein and a six-histidine tag which could be chelated with metal ions with a relatively high affinity. As a result, the purification is simplified and the stability of the protein was remarkably improved [20]. In the present study, we evaluated the direct radiosensitive effects of ES on human lung squamous carcinoma cells H-520 in vitro and also explored its mechanism of radiosensitization.

\section{Materials and methods \\ Cell lines and cell culture}

The human lung squamous cancer cell line H-520 was purchased from the Institute of Basic Medical Sciences Chinese Academy of Medical Sciences and cultured in DMEM supplemented with $100 \mathrm{IU} / \mathrm{mL}$ penicillin, 100 $\mathrm{mg} / \mathrm{mL}$ streptomycin, $4 \mathrm{mM}$ glutamine and $10 \%$ heatinactivated fetal bovine serum (Hangzhou Sijiqing Biological Engineering Materials Company, China) in a humidified atmosphere of $95 \%$ air and $5 \% \mathrm{CO}_{2}$ at $37^{\circ} \mathrm{C}$. ES-treated H-520 cells were obtained by culturing cells with $200 \mu \mathrm{g} / \mathrm{mL}$ ES (expressed and purified in E. coli. Simcere Pharmaceutical Research Co., Ltd) for $24 \mathrm{~h}$ before irradiation. Phospho-P38 mitogen-activated protein kinases (MAPK) mAb (Alexa Fluor) was provided by Cell Signaling Technology, US.

For all in vitro experiments, cells were released from flasks using phosphate- buffered saline containing $0.01 \%$ trypsin and $0.20 \mathrm{mmol} / \mathrm{L}$ EDTA, and $1 \times 10^{5}$ cells were plated onto $25 \mathrm{~cm}^{2}$ culture flasks one day before drug treatment. Cultures were between $50 \%$ and $70 \%$ confluence at the time of harvest.

\section{Cell growth assay}

Cells were maintained as mono-layer cultures in DMEM with $10 \% \mathrm{FBS}$ and antibiotics $(100 \mathrm{U} / \mathrm{ml}$ of penicillin and $100 \mathrm{mg} / \mathrm{ml}$ streptomycin). The cells were incubated in 5\% $\mathrm{CO}_{2}$ atmosphere. The studies were completed with $3 \times 10^{3}$ cells/well plated into 96-well flat bottom microplates (Costar), treated with ES of desired concentration when cells began to grow exponentially. After incubation for 24-96 h, $20 \mu \mathrm{L}$ of 3-(4,5-diethyl-2-thiazolyl)-2,5-diphenyl tetrazolium bromide (MTT $5 \mathrm{mg} / \mathrm{mL}$ ) was added to each well, and the cells were further incubated at $37^{\circ} \mathrm{C}$ for $4 \mathrm{~h}$. The medium was then removed and $200 \mu \mathrm{L}$ of DMSO was added to dissolve the reduced formazan product. The plate was then read on a microplate reader (BioRAD, model 550) at $590 \mathrm{~nm}$.

\section{lonizing radiation treatment}

Exponentially growing H-520 cells were irradiated using ${ }^{60} \mathrm{Co} \gamma$ ray source at $1.953 \mathrm{~Gy} / \mathrm{min}$ dose rate. Radiation was performed in the Radiation Department of Peking University.

\section{Clonogenic assay}

H-520 cells of the control and ES groups were exposed to different radiation doses $(0,1,2,4,6,8$ and 10 Gy) and incubated for $21 \mathrm{~d}$, then cells were fixed with methanol and stained with Giemsa. Cell colonies which contained more than 50 cells were manually counted. Radiation survival data from ES-treated cells were corrected for plating efficiency (PE) using an unirradiated plate treated with ES under the same conditions. The PE and survival fraction (SF) were calculated as follows: $\mathrm{PE}=$ (colony number/ inoculating cell number) $\times 100 \% . \mathrm{SF}=\mathrm{PE}$ (tested group)/ PE (0Gy group) $\times 100 \%$. A dose-survival curve was obtained for each experiment and used for calculating the radiobiological parameters. Three replicates were set at each radiation dose. The cell-survival curve was fitted using Origin 7.5 software according to the multi-target single-hit model after normalizing for the cytotoxicity induced by Endostar alone. The equation of SF $=1-\left(1-\mathrm{e}^{-\mathrm{D} /}\right.$ D0 $)^{\mathrm{N}}$ was applied to calculate the cellular radiosensitivity (mean lethal dose, $\mathrm{D}_{0}$ ), the capacity for sublethal damage repair (quasithreshold dose, Dq), and the extrapolation number $(\mathrm{N})$. Those values were used to calculate the SF after irradiation at a dose of $2 \mathrm{~Gy}\left(\mathrm{SF}_{2}\right)$ and the sensitization enhancement ratio (SER).

\section{Apoptosis assay}

Two methods were used to analysis apoptosis induced by ES. Morphological changes were determined by Hoechst33258 staining. Single cell suspensions in PBS were stained with $10 \mu \mathrm{g} / \mathrm{mL}$ Hoechst33258. A drop of the stained cell suspension was placed on a microscope slide. Cells were visualized under a fluorescence microscope with a blue filter. Apoptotic cells were defined as cells showing cytoplasmic and nuclear shrinkage and chromatin condensation or fragmentation morphologically. Annexin V-FITC and propidium iodide (PI) double staining were used for evaluation of cellular apoptosis rate. The $\mathrm{H}-520$ cells were treated with $200 \mu \mathrm{g} / \mathrm{mL}$ ES for $24 \mathrm{~h}$ and then irradiated with different doses of 0, 2, 4 and 8Gy. After a $72 \mathrm{~h}$ post- irradiation incubation period in $200 \mu \mathrm{g} /$ $\mathrm{mL}$, all cells were collected, stained with annexin V-FITC for $30 \mathrm{~min}$ at $4^{\circ} \mathrm{C}$, then stained with PI and analyzed by flow cytometry (FCM) immediately.

\section{Activated caspase proteins assayed by FCM}

$5 \times 10^{5} \mathrm{H}-520$ cells were harvested after treatment with irradiation for $24 \mathrm{~h}$. Then, washed once in $1 \mathrm{ml} \mathrm{PBS}$, and re-suspended in $200 \mu \mathrm{l}$ staining solution containing 
FITC-VAD-fmk (CaspACE, Promega). After incubation for $20 \mathrm{~min}$ at $30^{\circ} \mathrm{C}$, cells were washed in $1 \mathrm{ml}$ PBS and resuspended in $200 \mu \mathrm{l}$ PBS [21]. Samples were analyzed by FACScan using Coulter EPICS and ModFit software.

\section{Analysis of cell cycle by FCM}

H-520 cells from the control and ES groups were treated with irradiation ( 0 and $4 \mathrm{~Gy}$ ) and 8,24 , and $48 \mathrm{~h}$ later, cells were trypsinized, counted, washed, and re-suspended from all flasks. Cells were then fixed by dropwise addition of $70 \%$ ice-cold ethanol and stored at $4{ }^{\circ} \mathrm{C}$ until the day of analysis. Cells were then washed in phosphate-buffered saline, and re-suspended in PI solution at $50 \mu \mathrm{g} / \mathrm{mL}$ and analyzed by FCM using Coulter EPICS and ModFit software (Verity Software House, Topsham, MN).

\section{Phospho-P38-MAPK quantification by FCM}

$\mathrm{Bcl}-2$ and phosphor-p38-MAPK were quantified in control and ES-treated H-520 cells at $24 \mathrm{~h}$ after irradiation. Cells were stained with p38-MAPK mAb (Alexa Fluor) or Bcl-2 mAb (Beijing Zhongshan Golden Bridge Biotechnology Co., Ltd) and analyzed by FACScan using Coulter EPICS and ModFit software.

\section{Western blotting analysis}

$\mathrm{H}-520$ cells from the control and ES groups were treated with irradiation ( 0 and $4 \mathrm{~Gy}$ ), harvested and total cell lysates were resolved on $10 \%$ SDS-PAGE, and processed according to standard protocols. The antibodies (Abs) used for western blotting included: monoclonal anti- $\beta$ Actin (Sigma, USA), monoclonal antibody against phosphor-Akt (Beijing Zhongshan Golden Bridge Biotechnology Co., Ltd). Optimal dilutions of primary Abs were 1:1000 to 1:5000. The secondary Abs anti-rabbit were conjugated to horseradish peroxidase (dilution 1: 5000 to 1: 10000); signals were detected using the ECL system.

\section{Statistics}

Results are presented as mean \pm SE of at least three experiments. Student's $t$ test was used to assess the statistical significance of differences. A significance level threshold of $p<0.05$ was used in this study.

\section{Results}

\section{The effects of ES on cell proliferation}

The effect of ES on the proliferation of human lung squamous cancer cells $\mathrm{H}-520$ was first determined using MTT assay. As shown in Fig. 1, ES significantly inhibited the proliferation of $\mathrm{H} 520$ cells in a dose- and time-dependent manner, especially when the concentrations of ES were between 25 and $200 \mu \mathrm{g} / \mathrm{ml}$. Based on the present results, we chose $200 \mu \mathrm{g} / \mathrm{mL}$ ES as an appropriate concentration for the following experiments.

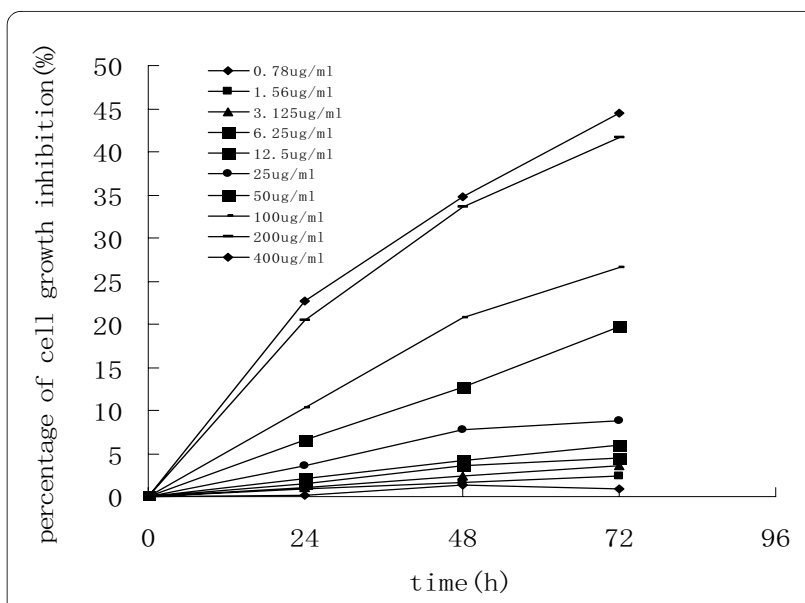

Figure $1 \mathrm{MTT}$ assay was used to evaluate the effect of ES on the growth of $\mathbf{H}-520$ cells. The exponentially growing $\mathrm{H}-520$ cells were seeded in 96-well plates and treated with increasing concentrations of ES for 24,48 and $72 \mathrm{~h}$. The results are presented as the percentage of the decreased values from the untreated cells. One representative of two identical experiments was shown.

\section{Radiosensitization of ES in $\mathrm{H}-520$ cells}

In the coming assays, we treated H-520 cells with ES in a dose of $200 \mu \mathrm{g} / \mathrm{mL}$ for $24 \mathrm{~h}$ before those cells received different doses of irradiation. The cell survival was detected by a clonogenic assay at $21 \mathrm{~d}$ after irradiation. As shown in Fig. 2, survival fraction of $\mathrm{H}-520$ cells at $2 \mathrm{~Gy}\left(\mathrm{SF}_{2}\right)$ was

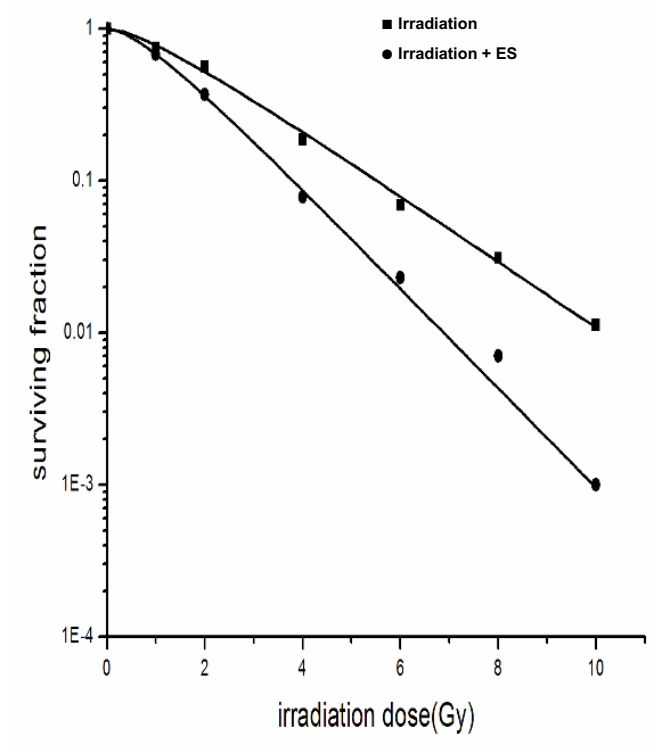

Figure 2 Clonogenic survival of $\mathrm{H}-520$ cells after different treatments including irradiation with or without ES. H-520 cells were treated with $200 \mu \mathrm{g} / \mathrm{mL}$ ES for $24 \mathrm{~h}$ and then washed. These ES-treated or control $\mathrm{H} 520$ cells received $0-10 \mathrm{~Gy}$ radiation and cloning formation was detected by 21 days after irradiation. Data were a summary of three experiments. 
0.56 vs. 0.37 and mean inactivation dose $\left(D_{0}\right)$ was $2 G y$ vs. $1.33 \mathrm{~Gy}$ in the absence and presence of ES pre-treatment respectively. The SER of ES in H-520 cells was 1.51 . The other radiobiological parameters of $\mathrm{H}-520$ cells were: $\mathrm{Dq}$ $=0.41 \mathrm{~Gy}, \mathrm{~N}=1.60$ and $\mathrm{D}_{10}=4.60 \mathrm{~Gy}$, whereas these parameters of ES-treated $\mathrm{H}-520$ cells were: $\mathrm{Dq}=0.34 \mathrm{~Gy}$, $\mathrm{N}=1.79$ and $\mathrm{D}_{10}=3.05 \mathrm{~Gy}$, respectively. These data indicated that ES had efficient radiosensitization effects on $\mathrm{H}-520$ cells in vitro.

\section{Cell death of $\mathrm{H}-\mathbf{5 2 0}$ cells induced by ES and irradiation}

To evaluate the induction of apoptosis after the combination of ES and irradiation, H-520 cells were treated with $200 \mu \mathrm{g} / \mathrm{mL}$ ES for $24 \mathrm{~h}$ immediately before irradiation. Apoptosis cell death was determined by fluorescence microscopy using cells stained with Hoechst 33258. H520 cells showed typical morphologic changes of apoptosis as cytoplasmic and nuclear shrinkage and chromatin condensation or fragmentation morphology (Fig. 3A).
The amount of apoptotic cells was determined by annexin V-FITC and PI double staining. As expected, more apoptotic cells were observed when the radiation doses increased (Fig. 3B and Table 1). Radiation induced significantly higher cell death in ES-pretreated H-520 cells than those in control $\mathrm{H}-520$ cells $(\mathrm{P}<0.05$ or $\mathrm{P}<$ 0.01 , Table 1).

\section{Effects of ES and irradiation on cell cycle progression of $\mathrm{H}$ - 520 cells}

$\mathrm{H}-520$ cells were treated with ES $(200 \mu \mathrm{g} / \mathrm{mL})$ for 12 to 48 $h$, the $G_{0} / G_{1}$ peak was increased and the $G_{2} / M$ peak decreased in a time-dependent style. There was no significant change in the S-phase after treated with ES for $12 \mathrm{~h}$, but a marked decrease was observed from 24 to $48 \mathrm{~h}$ after treatment with ES (Fig. 4 and Table 2). Exposed to 4Gy irradiation for $12-48 \mathrm{~h}$, the $\mathrm{G}_{0} / \mathrm{G}_{1}$ peak decreased, But the $\mathrm{G}_{2} / \mathrm{M}$ peak increased after irradiation during 12 to $24 \mathrm{~h}$ and decreased from 24 to $48 \mathrm{~h}$. However, the combination of ES and irradiation induced significantly decreased $\mathrm{G}_{0} /$
A

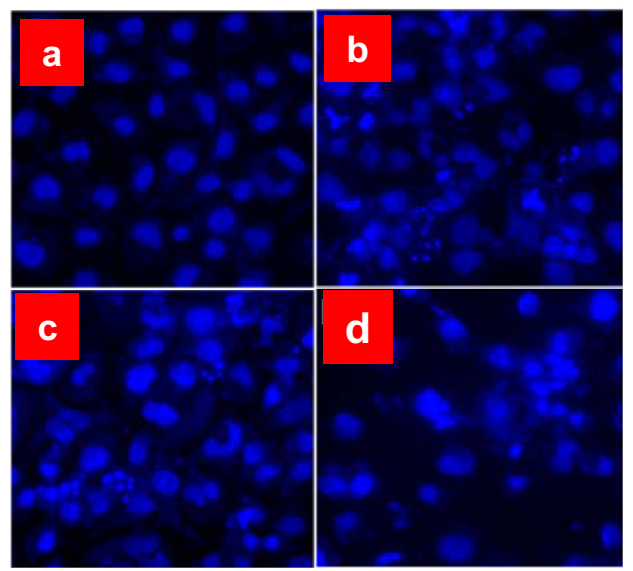

B

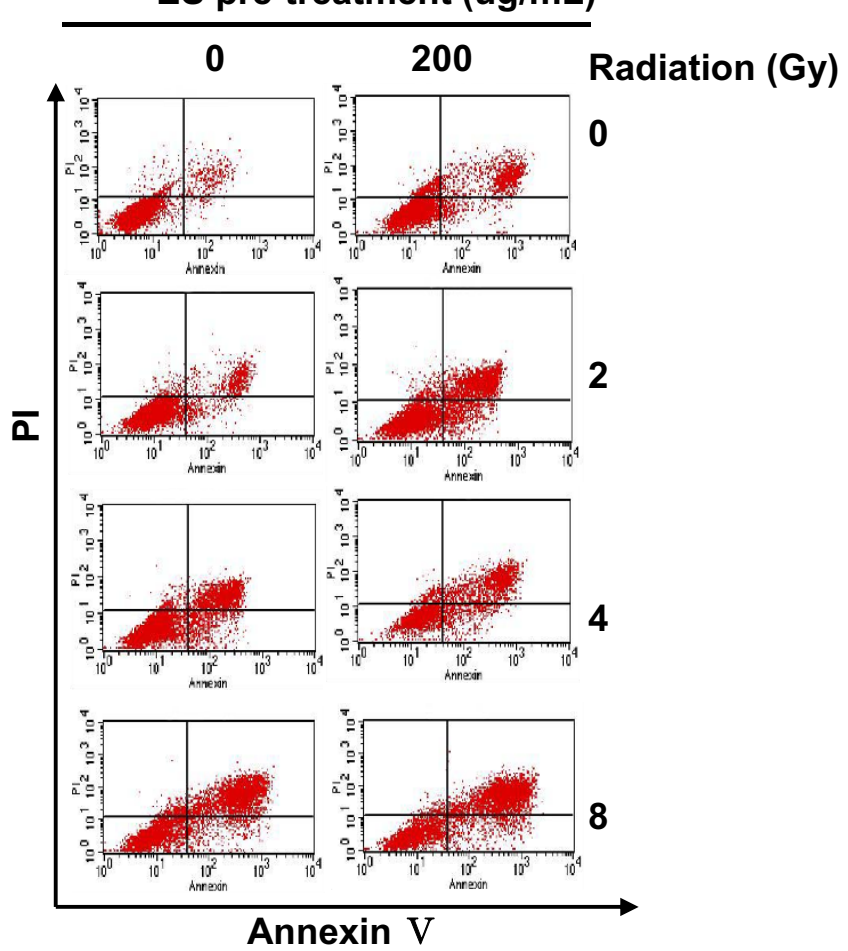

Figure $\mathbf{3}$ ES treatment significantly enhanced radiation-induced cell death in $\mathbf{H}-\mathbf{5 2 0}$ cells. A) Cell apoptosis observed by Hoechst 33258 staining ( $\times 400)$. H-520 cells treated with medium alone (a), $200 \mu \mathrm{g} / \mathrm{mL}$ ES (b), irradiation (c), and their combination (d) for 72 h. B) Cell death after different treatments was determined by a flow cytometry. The early apoptosis rate of ES-treated $\mathrm{H}-520$ cells was significantly higher than those of un-treated $\mathrm{H}-520$ cells at the radiation dosage of 4Gy. Higher total apoptosis rate of the ES-treated H-520 cells was observed at every radiation dose included in this study. One representative of three identical experiments was shown. 
Table 1: Effects of ES and irradiation on apoptosis in $\mathrm{H}-520$ cells $(\%, \bar{x} \pm \mathrm{s})$

\begin{tabular}{|c|c|c|c|c|}
\hline \multirow[t]{2}{*}{ Irradiation dose(Gy) } & \multicolumn{2}{|c|}{ H-520 cells } & \multicolumn{2}{|c|}{ ES-treated $\mathrm{H}-520$ cells } \\
\hline & Early apoptotic rate & Total apoptotic rate & Early apototic rate & Total apoptotic rate \\
\hline 0 & $0.57 \pm 0.03$ & $4.27 \pm 0.29$ & $4.59 \pm 0.48^{a}$ & $22.38 \pm 1.61^{b}$ \\
\hline 2 & $3.99 \pm 0.48$ & $14.3 \pm 1.15$ & $9.54 \pm 0.29 c$ & $35.01 \pm 1.16^{d}$ \\
\hline 4 & $6.8 \pm 0.26$ & $28.49 \pm 1.58$ & $12.08 \pm 0.25^{e}$ & $46.83 \pm 2.06^{f}$ \\
\hline 8 & $7.46 \pm 0.24$ & $54.79 \pm 1.89$ & $8.68 \pm 0.689$ & $64.08 \pm 4.28^{h}$ \\
\hline
\end{tabular}

Compared to the control H-520 cells irradiated with the same dose, $t=14.40, \mathrm{a} P<0.01 ; t=19.17, \mathrm{~b} P<0.01 ; t=17.15, \mathrm{c} P<0.01 ; t=17.79$, d $P<$ $0.01 ; t=25.64, \mathrm{e} P<0.01 ; t=25.64, \mathrm{f} P<0.01 ; t=2.93, \mathrm{~g} P<0.05 ; t=3.44, \mathrm{~h} P<0.05$.

$\mathrm{G}_{1}$ and $\mathrm{G}_{2} / \mathrm{M}$ phase cells but increased cells in $\mathrm{S}$ phase compared with control cells (Table 2).

\section{Effects of ES and irradiation on proteins involved in apoptosis}

Proteins involved in apoptosis including Bcl-2 and activated caspase which were tested by flow cytometry. The Bcl-2 expression was decreased in H-520 cells after the treatment with irradiation or ES, but less expression of Bcl-2 in H-520 cells was observed after the treatment with both ES and irradiation (Fig. 5A). On the other hand, the activated caspase level was up-regulated in irradiation- or ES- treated H-520 cells compared with control $\mathrm{H}-520$ cells. The combination of ES and irradiation induced significantly higher activated caspase level in $\mathrm{H}$ 520 cells compared with the control H-520 cells (Fig. 5B).

\section{Expression of phospho-p38-MAPK and p-Akt in H-520 cells after ES and irradiation treatment}

ES influenced signaling pathway, we examined the expression of the phosphorylation status of Akt by Western blotting and p38-MAPK by FCM, which mainly associated with mitogenicity and cell proliferation. As shown in Fig. 6A and Table 3, ES could significantly inhibit the phosphorylation of p38-MAPK in H-520 cells after treatment with irradiation or not. However, the level of phosphor-p38-MAPK in cells treated with irradiation and ES had no observed change. Western blotting analysis showed significant decrease of the phosphor-Akt expression in ES alone or combined with irradiation of 4Gy (Fig. 6B). Nevertheless, no significant changes of expression of phosphor-Akt were observed in irradiation-treated $\mathrm{H}$ 520 cells.

\section{Discussion}

It is known that ED inhibits the angiogenesis of malignant diseases, but it does not inhibit the functions of cancer cells. However, recent studies showed that ED possess direct antitumor activity on cancer cell migration, metastasis, and proliferation [11,17,21-23]. ES, a novel recombinant human ED, has been demonstrated to inhibit the proliferation and migration of human umbilical vein endothelial cells $\left(\mathrm{HUNEC}_{\mathrm{S}}\right.$ ) and the invasion of MDAMB-435 human breast cancer cells $[19,24]$. But weather it suppress the cell proliferation of cancer cells has not been reported. In the present study, we showed the first evidence that ES directly inhibits the proliferation of human lung squamous cancer cells $\mathrm{H}-520$ and induces $\mathrm{H}-520$ cell apoptosis. Moreover, ES could enhance the sensitivity of $\mathrm{H}-520$ cells to irradiation.

It has been reported that ED enhanced the anti-tumor effects of ionizing irradiation in vivo [25-29]. ES significantly inhibited the proliferation of $\mathrm{H}-520$ cells in a doseand time- dependent manner as determined by an MTT assay. The dose-survival curves of ES-treated H-520 cells exhibited a narrower shoulder and a greater slope rate which standard for quasi-threshold doses $\left(D_{q}\right)$ and mean lethal doses $\left(D_{0}\right)$ respectively. It indicates that the repair of sublethal damages and sensitivity to lethal radiation dose was decreased. A significant radiosensitivity effect with the sensitization enhancement ratio (SER) is 1.51 . So our findings showed that ES could enhance the sensitivity of $\mathrm{H}-520$ cells to irradiation and had the potential to be a radiosensitizer.

The mechanisms of ES improved $\mathrm{H}-520$ cell response to radiation were multiple, especially in the in vivo models [30-32]. ES could inhibit the proliferation of endothelial cells and cancer cells, and induced cell apoptosis, both of which reduce the total tumor cell mass, making tumors more amenable to control by radiotherapy [11,18,33-35]. The cell cycle phases also determined $\mathrm{H}-520$ cancer cells relative to radiosensitivity, with $\mathrm{H}-520$ cells being most radiosensitive in the $G_{2} / M$ phase, less sensitive in the $G_{0} /$ $G_{1}$ phase, and least sensitive during the latter part of the $S$ phase [36]. It was demonstrated that ED induced a cell cycle arrest mainly in the $G_{0} / G_{1}$ phase and a decrease in the $S$ phase [37-39]. In the current study, we observed a clear cell arrest in the $G_{0} / G_{1}$ phase and a reduction in the $\mathrm{H}-520$ cells of $\mathrm{S}$ phase in ES-treated $\mathrm{H}-520$ cells with a time-dependent style. H-520 cells progressing past the $\mathrm{G}_{1} / \mathrm{S}$ block might accumulate proapoptotic signals caused 


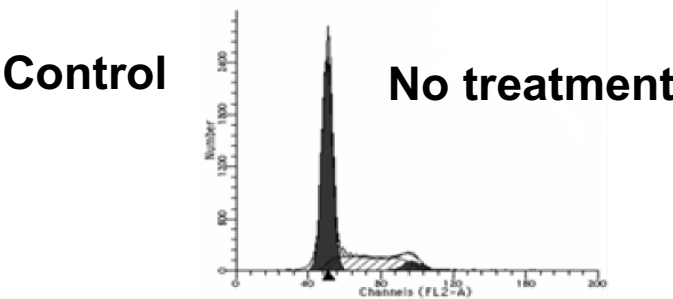

Time after
irradiation

$12 \mathrm{~h}$

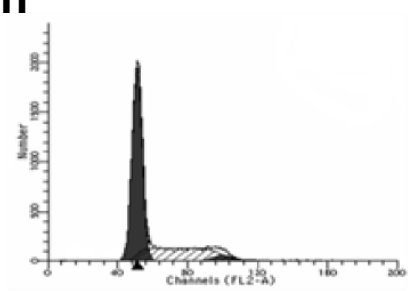

ES

$24 \mathrm{~h}$
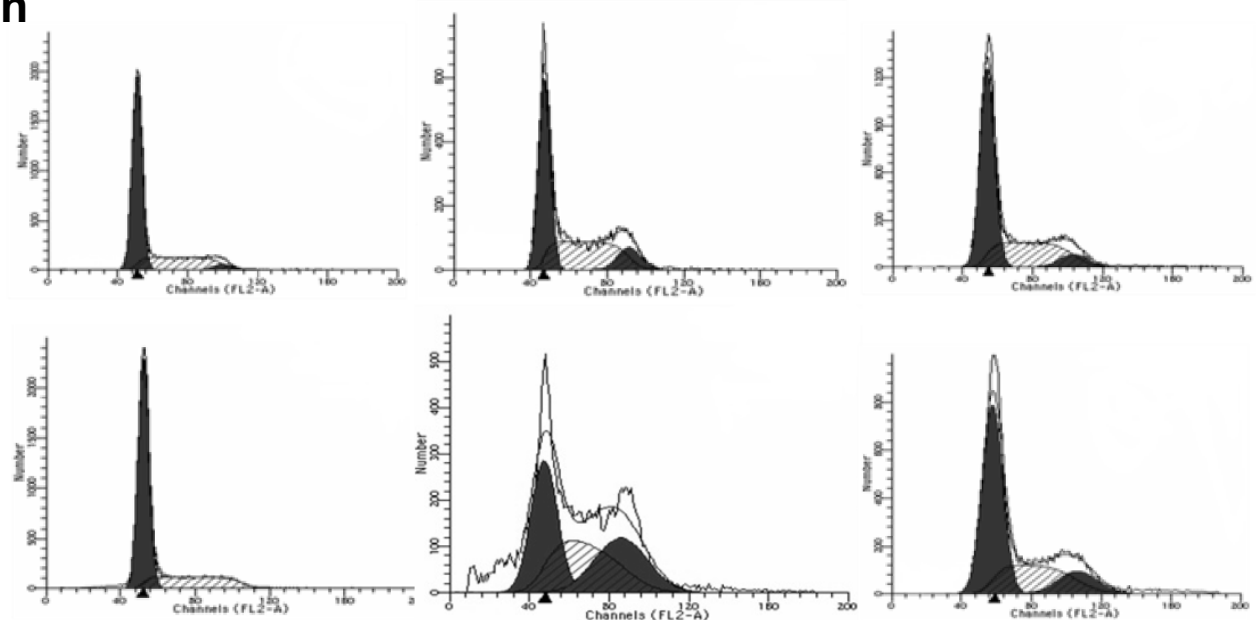

$48 \mathrm{~h}$
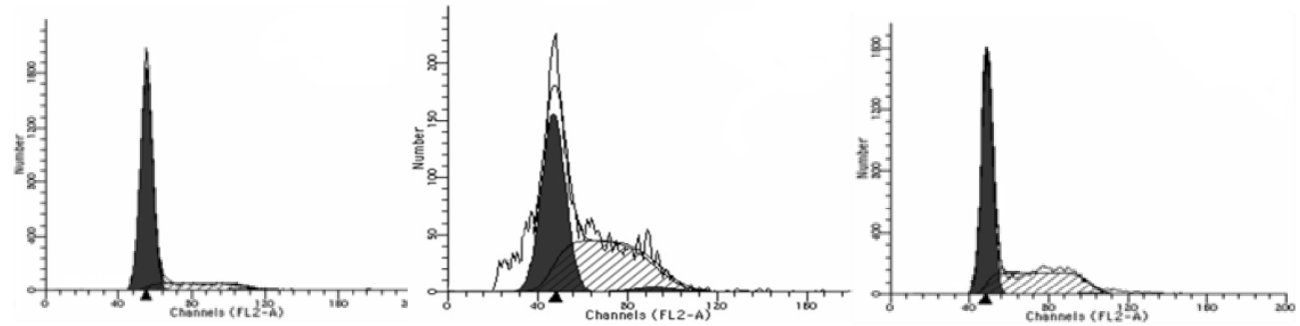

Figure 4 Cell cycle distribution of $\mathrm{H}-520$ cells after treatment with $\mathrm{ES}$ and/or $4 \mathrm{~Gy}$ irradiation from 12 to $48 \mathrm{~h}$ in $\mathrm{H}-520$ cells. One representative of two independent experiments with similar results was shown.

by both radiation and ES, resulting in increased H-520 cell death [40]. Radiation alone or the combination of radiation and ES promoted significantly higher percentages of cells in $\mathrm{G} 2 / \mathrm{M}$ phase at $24 \mathrm{~h}$ after treatment, though the combination of radiation and ES showed less effect than radiation alone in this respect. These data indicate that radiation induces a cell cycle arrest in G2/M phase in $\mathrm{H}-520$ cells at the early time points. However, in the later stage, more cells in this phase will process cell death so the percentage of cells in G2/M phase will decrease dramatically, as seen in $48 \mathrm{~h}$ after radiation.
A fundamental view on apoptosis was that apoptotic signaling transduction act mostly upon pathways initiating from mitochondria and they eventually met at the level of Bcl-2 family members and the caspases, an ultimate executioners of cell death [41]. It has been reported that ED induced apoptosis in several cancer cells $[11,18]$, and it also has been reported that ED induced apoptosis in endothelial cells in a caspase-dependent manner, and ED-mediated apoptosis is associated with several apoptotic signaling pathways including overloading of intracellular magnesium and calcium, as well as regulation of p53 and Bcl-2 expression $[10,42,43]$. In the present study, 
Table 2: Cell cycle distribution in H-520 cell line after treatment with ES and irradiation(\%, $\bar{x} \pm \mathrm{s})$

\begin{tabular}{|c|c|c|c|c|}
\hline Group & Treatment & G0/G1 & $\mathbf{S}$ & G2/M \\
\hline $\mathrm{Oh}$ & No treatment & $66.15 \pm 1.01$ & $28.18 \pm 1.23$ & $5.66 \pm 0.22$ \\
\hline \multirow[t]{3}{*}{$12 \mathrm{~h}$} & ES & $66.03 \pm 1.46$ & $30.66 \pm 2.55$ & $3.31 \pm 1.10^{\mathrm{a}}$ \\
\hline & 4Gy & $47.27 \pm 1.25^{b}$ & $41.1 \pm 1.67 c$ & $11.63 \pm 1.65^{d}$ \\
\hline & $E S+4 G y$ & $58.62 \pm 3.84 e^{2}$ & $34.32 \pm 2.88^{f}$ & $7.06 \pm 0.97$ \\
\hline \multirow[t]{3}{*}{$24 \mathrm{~h}$} & ES & $72.36 \pm 2.149$ & $27.03 \pm 1.71$ & $0.61 \pm 0.54^{h}$ \\
\hline & $4 \mathrm{~Gy}$ & $35.79 \pm 1.43^{i}$ & $33.94 \pm 1.79 j$ & $30.23 \pm 0.43^{k}$ \\
\hline & $E S+4 G y$ & $57.34 \pm 2.26$ & $29.11 \pm 2.39$ & $13.55 \pm 0.78^{m}$ \\
\hline \multirow[t]{3}{*}{$48 \mathrm{~h}$} & ES & $82.72 \pm 3.32^{n}$ & $15.06 \pm 3.13^{\circ}$ & $2.22 \pm 0.94 p$ \\
\hline & 4Gy & $48.85 \pm 3.28 q$ & $48.12 \pm 2.10^{r}$ & $3.03 \pm 1.35^{\mathrm{s}}$ \\
\hline & $\mathrm{ES}+4 \mathrm{~Gy}$ & $57.78 \pm 1.46^{t}$ & $41.44 \pm 1.08^{u}$ & $0.78 \pm 0.39^{v}$ \\
\hline
\end{tabular}

Compared with $0 \mathrm{~h}$ group, $\mathrm{t}=3.63$, a $<<0.05 ; \mathrm{t}=20.36$, bP $<0.01 ; \mathrm{t}=-10.79, \mathrm{cP}<0.01 ; \mathrm{t}=-6.22, \mathrm{dP}<0.01 ; \mathrm{t}=3.29, \mathrm{eP}<0.05 ; \mathrm{t}=-3.40, \mathrm{f} P<0.05$; $\mathrm{t}=-4.54, \mathrm{gP}<0.05 ; \mathrm{t}=14.94, \mathrm{hP}<0.01 ; \mathrm{t}=30.12, \mathrm{P}<0.01 ; \mathrm{t}=-4.60, \mathrm{jP}<0.05 ; \mathrm{t}=-87.69, \mathrm{kP}<0.01 ; \mathrm{t}=6.17, \mathrm{P}<0.01 ; \mathrm{t}=-16.92, \mathrm{mP}<0.01 ; \mathrm{t}=-$ $8.28, \mathrm{nP}<0.01 ; \mathrm{t}=6.76,{ }^{\circ} \mathrm{P}<0.01 ; \mathrm{t}=6.15, \mathrm{pP}<0.01 ; \mathrm{t}=8.75, \mathrm{qP}<0.01 ; \mathrm{t}=-14.18, \mathrm{rP}<0.01 ; \mathrm{t}=3.33, \mathrm{sP}<0.05 ; \mathrm{t}=8.16, \mathrm{tP}<0.01 ; \mathrm{t}=-14.08, \mathrm{uP}$ $<0.01 ; \mathrm{t}=18.82, \mathrm{VP}<0.01$.
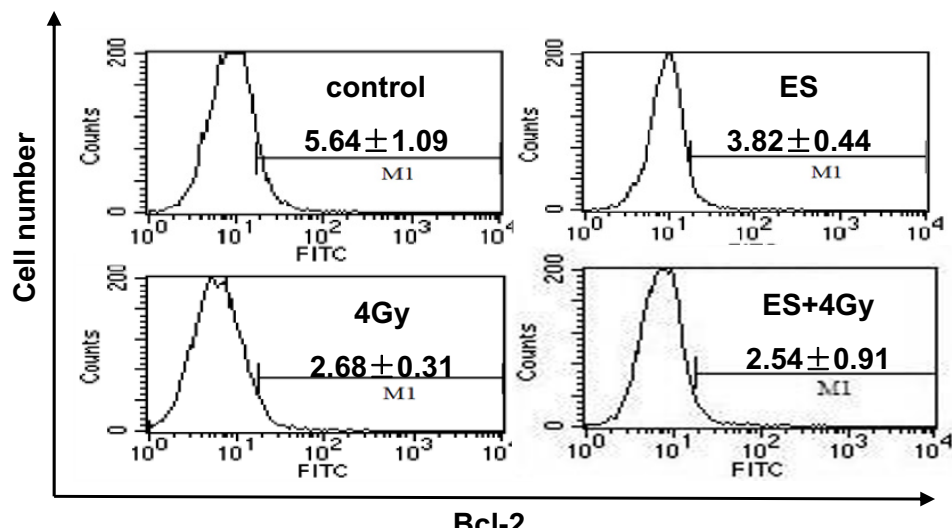

Bcl-2

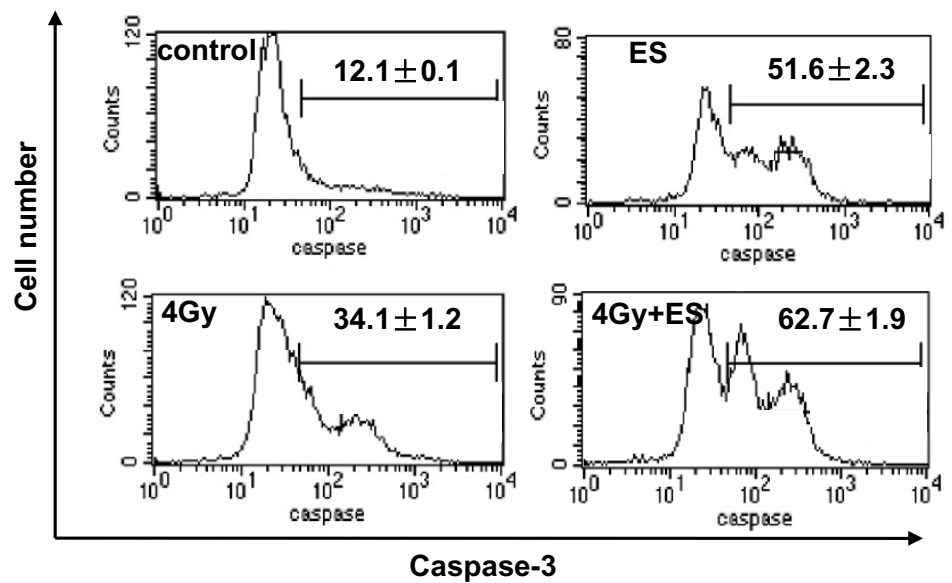

Figure $5 \mathrm{Bcl}-2$ and activated caspase protein level in $\mathrm{H}-520$ cells after treatment with ES and 4Gy irradiation were detected by a flow cytometry. A) Decreased Bcl-2 expression in ES and radiation-treated H-520 cells. B) Increased activated caspase level in H-520 cells induced by ES and irradiation. Data were presented as mean $\pm S D(N=4)$. One representative of four identical experiments was shown. 

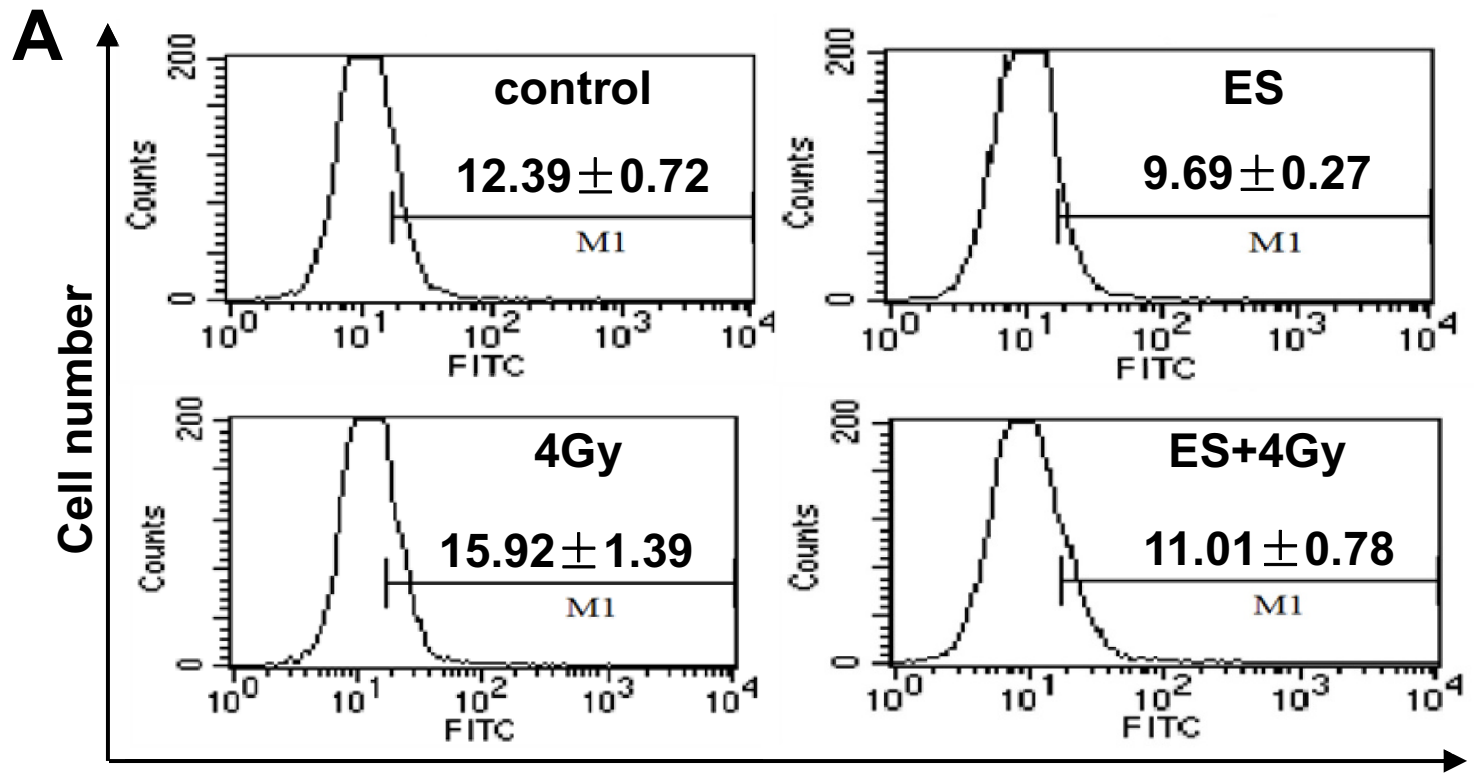

B

p38-MAPK

\begin{tabular}{|c|c|c|c|c|}
\hline- & + & + & - & $4 G y$ \\
\hline- & + & - & + & ES \\
\hline
\end{tabular}

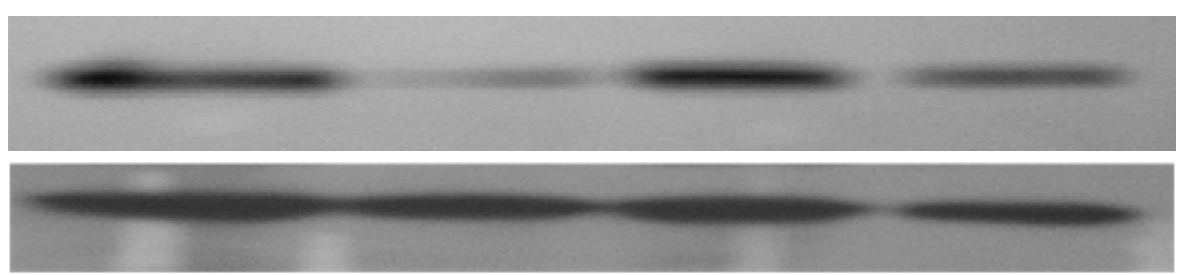

p-AKT

Actin

Figure 6 Phosphorylation level of p38-MAPK and Akt in H-520 cells after irradiation and ES treatment. A) ES combined with 4Gy irradiation significantly inhibits p38-MAPK phosphorylation. B) Decreased p-Akt in H-520 cells caused by ES treatment. Protein extracts of cells treated with 200 $\mu \mathrm{g} / \mathrm{mL}$ ES, 4Gy irradiation, and in combination (ES+4Gy) at $24 \mathrm{~h}$ following irradiation. One representative of three independent experiments was shown.

Table 3: Expressions of phospho-p38-MAPK in H-520 cells ( $\bar{x} \pm s)$

\section{Flurescence intensity}

Group

control

ES

Irradiation

ES+ irradiation
Phospho-p38-MAPK(-)\%

$87.61 \pm 0.72$
$90.31 \pm 0.27^{a}$
$84.08 \pm 1.39 c$
$88.99 \pm 0.78$

Phospho-p38-MAPK(+)\%

$12.39 \pm 0.72$

$9.69 \pm 0.27^{b}$

$15.92 \pm 1.39^{d}$

$11.01 \pm 0.78$ 
we evaluated apoptosis in H-520 cells after ES combination with irradiation treatment from morphological and quantitative aspects, which showed a significant increase in $\mathrm{H}-520$ cellular apoptosis. Consistently, the levels of $\mathrm{Bcl}-2$ protein in $\mathrm{H}-520$ cells were decreased after treatment and the level of activated caspase proteins was increased. These changes in combination treatment group were significantly greater than that in single treatment group and is consistent with the previous studies $[10,42]$.

Previous studies showed that the PI3K-Akt pathway and MAPKs have a significant effect on the cell survival of cancer cells and play an important role in the antiapoptotic effects of growth factors $[44,45]$. There are four distinct subfamilies in the MAPK family: ERKs (ERK1 and ERK2), p38 MAPK, JNK/SAPK, and ERK5/BMK1. Among them, p38 MAPK is closely related to the apoptosis of a variety of cells [46-48]. The Akt protein played a key role in a pathway related to survival by inhibition of apoptotic signals and promotion of cell cycle progression, with a clear implication in cancer and other pathologies. Also, Akt has been shown to be potently activated in response to a wide variety of growth factors and in response to DNA damage [49]. It was demonstrated that ES suppress the activation of ERKs, p38 MAPK, and Akt in HUVECs or retinal microvascular endothelial cells (RMECs) $[49,50]$. In the present study, ES combined with irradiation significantly reduce the phosphorylation of p38-MAPK protein and Akt protein, which probably be the mechanism leading to the increased apoptosis of $\mathrm{H}$ 520 after treatment.

In conclusion, ES significantly inhibited cell proliferation and induced apoptosis in human lung squamous cancer cell line $\mathrm{H}-520$ and has the potential to be a radiosensitizer, which may due to the cell cycle redistribution, increase of cell apoptosis and influences on the PI3K-Akt pathway and MAPKs. The present data offer basic information of the combining ES and irradiation on tumor treatment, which may have clinical significance.

\footnotetext{
Abbreviations

ED: recombinant human endostatin; ES: Endostar; PE: plating efficiency; SF survival fraction; $\mathbf{S E R}$ : sensitization enhancement ratio; $\mathbf{D}_{\mathbf{0}}$ : mean lethal dose; mean inactivation dose, $\mathbf{D}_{\mathbf{q}}$ : quasithreshold dose; $\mathbf{N}$ : extrapolation number; $\mathrm{SF}_{2}$ : surviving fraction after 2Gy irradiation; $\mathbf{M T T}$ : methyl thiazolyl tetrazolium; FCM: flow cytometry; NSCLC: non-small cell lung cancer; HUVEC : human umbilical vein endothelial cells.
}

\section{Competing interests}

The authors declare that they have no competing interests.

\section{Authors' contributions}

ZYY carried out cell colony-forming assay, fluorescence-activated cell sorting, flow cytometric analysis, and drafted the manuscript. JJW participated in its design and revised the manuscript. FL performed the statistical analysis. YDZ carried out the irradiation experiment. YZ supervised experimental work and revised the manuscript. All authors read and approved the final manuscript.

\section{Acknowledgements}

The authors wish to thank Ms. Jing Wang and Ms. Jianxia Peng for their expert technical assistance, Ms. Qinghuan Li for her excellent laboratory management. This work was partially supported by grants from the Ministry of Civil Affair, China (2007 18, to JW) and Chinese Academy of Sciences (KJCX2-YWL08, to YZ). The funding body plays an importamt role in the decision to submit the manuscript for publication.

\section{Author Details}

${ }^{1}$ Cancer Center, Department of Radiation Oncology, Peking University Third Hospital, Beijing 100191, China and 2Transplantation Biology Research Division, State Key Laboratory of Biomembrane and Membrane Biotechnology, Institute of Zoology, Chinese Academy of Sciences, Beijing 100101, China

Received: 13 March 2010 Accepted: 24 May 2010

Published: 24 May 2010

\section{References}

1. Govindan R, Bogart J, Vokes EE: Locally advanced non - small cell lung cancer: the past, present, and future. J Thorac Oncol 2008, 3:917-28.

2. Bayman NA, Blackhall F, Jain P, Lee L, Thatcher N, Faivre FC: Management of unresectable stage III non - small - cell lung cancer with combined modality therapy: a review of the current literature and recommendations for treatment. Clin lung cancer 2008, 9:92-101.

3. Bunn PA Jr, Thatcher N: Systemic treatment for advanced (stage IIIb/IV) non - small cell lung cancer: more treatment options; more things to consider. Introduction. Oncologist 2008, 13(Suppl 1):1-4

4. Marom EM, Martinez CH, Truong MT, Lei X, Sabloff BS, Munden RF, Gladish GW, Herbst RS, Morice RC, Stewart DJ, Jimenez CA, Blumenschein GR Jr, Onn A: Tumor cavitation during therapy with antiangiogenesis agents in patients with lung cancer. J Thorac Onco/ 2008, 3:351-7.

5. Folkman J: Antiangiogenesis in cancer therapy - endostatin and its mechanisms of action. Exp Cell Res 2006, 312:594-607.

6. Moniz M, Yeatermeyer J, Wu TC: Control of cancers by combining antiangiogenesis and cancer immunotherapy. Drug Today 2005, 41:471-94.

7. Huber PE, Bischof M, Jenne J, Heiland S, Peschke P, Saffrich R, Grone HJ, Debus J, Lipson KE, Abdollahi A: Trimodal cancer treatment: beneficial effects of combined antiangiogenesis, radiation, and chemotherapy. Cancer Res 2005, 65:3643-55.

8. O'Reilly MS, Boehm T, Shing Y, Fukai N, Vasios G, Lane WS, Flynn E, Birkhead JR, Olsen BR, Folkman J: Endostatin: an endogenous inhibitor of angiogenesis and tumor growth. Cell 1997, 88:277-85.

9. Dhanabal M, Ramchandran R, Volk R, Stillman IE, Lombardo M, IruelaArispe ML, Simons M, Sukhatme VP: Endostatin: yeast production, mutants, and antitumor effect in renal cell carcinoma. Cancer Res 1999, 59:189-97.

10. Dhanabal M, Ramchandran R, Waterman MJ, Lu H, Knebelmann B, Segal M, Sukhatme VP: Endostatin induces endothelial cell apoptosis. J Biol Chem 1999, 274:11721-6.

11. Dkhissi F, Lu H, Soria C, Opolon P, Griscelli F, Liu H, Khattar P, Mishal Z, Perricaudet M, Li H: Endostatin exhibits a direct antitumor effect in addition to its antiangiogenic activity in colon cancer cells. Hum Gene Ther 2003, 14:997-1008.

12. Dixelius J, Larsson H, Sasaki T, Holmqvist K, Lu L, Engstrom A, Timpl R, Welsh M, Claesson-Welsh L: Endostatin - induced tyrosine kinase signaling through the Shb adaptor protein regulates endothelial cell apoptosis. Blood 2000, 95:3403-11.

13. Mallery SR, Morse MA, Wilson RF, Pei P, Ness GM, Bradburn JE, Renner RJ, Schuller DE, Robertson FM: AIDS-related Kaposi's sarcoma cells rapidly internalize endostatin, which co - localizes to tropomysin microfilaments and inhibits cytokine-mediated migration and invasion. J Cell Biochem 2003, 89:133-43.

14. Shi H, Huang Y, Zhou H, Song X, Yuan S, Fu Y, Luo Y: Nucleolin is a receptor that mediates antiangiogenic and antitumor activity of endostatin. Blood 2007, 110:2899-906.

15. Rehn M, Veikkola T, Kukk-Valdre E, Nakamura H, Ilmonen M, Lombardo C, Pihlajaniemi T, Alitalo K, Vuori K: Interaction of endostatin with integrins implicated in angiogenesis. Proc Natl Acad Sci USA 2001, 98:1024-9.

16. Karumanchi SA, Jha V, Ramchandran R, Karihaloo A, Tsiokas L, Chan B, Dhanabal M, Hanai Jl, Venkataraman G, Shriver Z, Keiser N, Kalluri R: Cell 
surface glypicans are low - affinity endostatin receptors. Mol Cell 2001, 7:811-22.

17. Wilson RF, Morse MA, Pei P, Renner RJ, Schuller DE, Robertson FM, Mallery SR: Endostatin inhibits migration and invasion of head and neck squamous cell carcinoma cells. Anticancer Res 2003, 23:1289-95.

18. Cui R, Ohashi R, Takahashi F, Yoshioka M, Tominaga S, Sasaki S, Gu T, Takagi $Y$, Takahashi K: Signal transduction mediated by endostatin directly modulates cellular function of lung cancer cells in vitro. Cancer Sci 2007, 98:830-7.

19. Ling Y, Yang Y, Lu N, You QD, Wang S, Gao Y, Chen Y, Guo QL: Endostar, a novel recombinant human endostatin, exerts antiangiogenic effect via blocking VEGF - induced tyrosine phosphorylation of KDR/Flk - 1 of endothelial cells. Biochem Bioph Res Comm 2007, 361:79-84.

20. Song HF, Liu XW, Zhang HN, Zhu BZ, Yuan SJ, Liu SY, Tang ZM: Pharmacokinetics of His-tag recombinant human endostatin in Rhesus monkeys. Acta Pharmacol Sin 2005, 26:124-8.

21. Madeo F, Herker E, Maldener C, Wissing S, Lachelt S, Herlan M, Fehr M, Lauber K, Sigrist SJ, Wesselborg S, Frohlich KU: A caspase - related protease regulates apoptosis in yeast. Mol Cell 2002, 9:911-7.

22. Yokoyama Y, Sedgewick G, Ramakrishnan S: Endostatin binding to ovarian cancer cells inhibits peritoneal attachment and dissemination. Cancer Res 2007, 67:10813-10822.

23. Yokoyama Y, Ramakrishnan S: Binding of endostatin to human ovarian cancer cells inhibits cell attachment. Int J Cancer 2007, 121:2402-9.

24. Lu N, Ling Y, Gao Y, Chen Y, Mu R, Qi Q, Liu W, Zhang H, Gu H, Wang S, Yang Y, Guo Q: Endostar suppresses invasion through downregulating the expression of matrix metalloproteinase - 2/9 in MDA-MB-435 human breast cancer cells. Exp Biol Med 2008, 233:1013-20.

25. Hanna NN, Seetharam S, Mauceri HJ, Beckett MA, Jaskowiak NT, Salloum RM, Hari D, Dhanabal M, Ramchandran R, Kalluri R, Sukhatme VP, Kufe DW, Weichselbaum RR: Antitumor interaction of short-course endostatin and ionizing radiation. Cancer $J$ 2000, 6:287-93.

26. Shi W, Teschendorf C, Muzyczka N, Siemann DW: Gene therapy delivery of endostatin enhances the treatment efficacy of radiation. Radiother Oncol 2003, 66:1-9.

27. Fenton BM, Paoni SF, Grimwood BG, Ding I: Disparate effects of endostatin on tumor vascular perfusion and hypoxia in two murine mammary carcinomas. Int J Radiat Oncol Biol Phys 2003, 57:1038-46.

28. Wen QL, Meng MB, Yang Bo, Tu LL, Jia LL, Zhou X: Endostar, a recombined humanized endostatin, enhances the radioresponse for human nasopharyngeal carcinoma and human lung adenocarcinoma xenografts in mice. Cancer Science 2009, 100:1510-9.

29. Itasaka S, Komaki R, Herbst RS, Shibuya K, Shintani T, Hunter N.R, Onn A, Bucana CD, Milas L, Ang KK, O'Reilly MS: Endostatin improves radioresponse and blocks tumor revascularization after radiation therapy for A431 xenografts in mice. Int J Radiat Oncol Biol Phys 2007, 67:870-8

30. Wu DS, Wu CM, Huang TH, Xie QD: Combined effects of radiotherapy and endostatin gene therapy in melanoma tumor model. Radiat Environ Biophys 2008, 47:285-91.

31. Greenberger JS: Antitumor interaction of short course endostatin and ionizing radiation. Cancer $J$ 2000, 6:279-81.

32. Oehler C, Dickinson DJ, Broggini-Tenzer A, Hofstetter B, Hollenstein A, Riesterer O, Vuong V, Pruschy M: Current concepts for the combined treatment modality of ionizing radiation with anticancer agents. Curr Pharm Design 2007, 13:519-35

33. Du Z, Hou S: The anti - angiogenic activity of human endostatin inhibits bladder cancer growth and its mechanism. J Urol 2003, 170:2000-3.

34. Raut CP, Takamori RK, Davis DW, Sweeney GB, O'Reilly MS, McConkey DJ: Direct effects of recombinant human endostatin on tumor cell IL-8 production are associated with increased endothelial cell apoptosis in an orthotopic model of human pancreatic cancer. Cancer Biol Ther 2004, 3:679-87.

35. te Velde EA, Reijerkerk A, Brandsma D, Vogten JM, Wu Y, Kranenburg O Voest EE, Gebbink M, Borel Rinkes IH: Early endostatin treatment inhibits metastatic seeding of murine colorectal cancer cells in the liver and their adhesion to endothelial cells. Br J Cancer 2005, 92:729-35.

36. Pawlik TM, Keyomarsi K: Role of cell cycle in mediating sensitivity to radiotherapy. Int J Radiat Oncol Biol Phys 2004, 59:928-42.

37. Xu R, Du P, Fan JJ, Zhang Q, Li TP, Gan RB: High - level expression and secretion of recombinant mouse endostatin by Escherichia coli. Protein Expres Purif 2002, 24:453-9.
38. Hanai J, Dhanabal M, Karumanchi SA, Albanese C, Waterman M, Chan B, Ramchandran R, Pestell R, Sukhatme VP: Endostatin causes G1 arrest of endothelial cells through inhibition of cyclin D1. J Biol Chem 2002, 277:16464-9.

39. Dhanabal M, Volk R, Ramchandran R, Simons M, Sukhatme VP: Cloning, expression, and in vitro activity of human endostatin. Biochem Biophy Res Comm 1999, 258:345-2.

40. Pauwels B, Korst AE, Pattyn GG, Lambrechts HA, Van Bockstaele DR, Vermeulen K, Lenjou M, de Pooter CM, Vermorken JB, Lardon F: Cell cycle effect of gemcitabine and its role in the radiosensitizing mechanism in vitro. Int J Radiat Oncol Biol Phys 2003, 57:1075-83.

41. Orrenius S: Mitochondrial regulation of apoptotic cell death. Toxicol Lett 2004, 149:19-23.

42. Ren B, Wang Y, Ndebele K, Zhi Q, Chen FH, Wang YZ, Parangi S: Multiple signaling is involved in endostatin - mediated apoptosis in ECV 304 endothelial cells. Front Biosci 2005, 10:1089-97.

43. Davis DW, Shen Y, Mullani NA, Wen S, Herbst RS, O'Reilly M, Abbruzzese JL, McConkey DJ: Quantitative analysis of biomarkers defines an optimal biological dose for recombinant human endostatin in primary human tumors. Clin Cancer Res 2004, 10:33-42.

44. Johnson GE, Ivanov VN, Hei TK: Radiosensitization of melanoma cells through combined inhibition of protein regulators of cell survival. Apoptosis 2008, 13:790-802.

45. Gupta VK, Jaskowiak NT, Beckett MA, Mauceri HJ, Grunstein J, Johnson RS, Calvin DA, Nodzenski E, Pejovic M, Kufe DW, Posner MC, Weichselbaum RR: Vascular endothelial growth factor enhances endothelial cell survival and tumor radioresistance. Cancer $J$ 2002, 8:47-54

46. Choi CH, Xu H, Bark H, Lee TB, Yun J, Kang SI, Oh YK: Balance of NF kappaB and $\mathrm{p} 38 \mathrm{MAPK}$ is a determinant of radiosensitivity of the AML 2 and its doxorubicin-resistant cell lines. Leukemia Res 2007, 31:1267-76.

47. Anoopkumar-Dukie S, Conere T, Carey JB, Allshire A: Radical mediators and mitogen - activated protein kinase signaling in oxygen dependent radiosensitivity of human tumor cell lines. Free Radical Bio Med 2005, 39:188-94.

48. Kumar P, Miller Al, Polverini PJ: p38 MAPK mediates gamma - irradiation induced endothelial cell apoptosis, and vascular endothelial growth factor protects endothelial cells through the phosphoinositide 3 kinase - Akt - Bcl-2 pathway. J Biol Chem 2004, 279:43352-60.

49. Viniegra JG, Martinez N, Modirassari P, Losa JH, Parada CC, Lobo VJ, Lobo VJ, Luquero Cl, Alvarez-Vallina L, Ramon CS, Rojas JM, Sanchez-Prieto R: Full activation of $\mathrm{PKB} / \mathrm{Akt}$ in response to insulin or ionizing radiation is mediated through ATM. J Biol Chem 2005, 280:4029-36.

50. Campbell M, Collery R, McEvoy A, Gardiner TA, Stitt AW, Brankin B: Involvement of MAPKs in endostatin - mediated regulation of blood retinal barrier function. Curr Eye Res 2006, 31:1033-45.

\section{doi: 10.1186/1475-2867-10-17}

Cite this article as: You et al., The radiosensitization effects of Endostar on human lung squamous cancer cells H-520 Cancer Cell International 2010, 10:17

\section{Submit your next manuscript to BioMed Centra and take full advantage of:}

- Convenient online submission

- Thorough peer review

- No space constraints or color figure charges

- Immediate publication on acceptance

- Inclusion in PubMed, CAS, Scopus and Google Scholar

- Research which is freely available for redistribution 